\title{
Autograph Assisted Mathematics Module Development to Improve Problem Solving Abilities and Mathematic Connection of High School Students
}

\author{
Dewi Anggraini Edi Syahputra Waminton Rajagukguk \\ State University of Medan, Jl. Willem Iskandar Psr. V Medan, Indonesia
}

\begin{abstract}
This study aims to determine: (1) the level of validity and effectiveness of the autograph-assisted mathematics module to improve the problem-solving abilities and mathematical connection abilities of the students of SMA MAN 1 Deli Serdang, (2) to increase the students 'mathematical problem solving abilities in the application of autograph-assisted mathematics modules, (3) to increase the students' mathematical connection abilities in application autograph-assisted math module.Researchers develop teaching materials in the form of autographassisted mathematics modules using the Dick \& Carey development model. The module validation was carried out by three experts and two practitioners.
\end{abstract}

Keywords: Development, Mathematics Module, Autograph, Problem Solving and Mathematical Connections DOI: $10.7176 / \mathrm{JEP} / 11-35-02$

Publication date: December $31^{\text {st }} 2020$

\section{PRELIMINARY}

In the mathematics learning process there are several learning components that affect the achievement of learning objectives. One of the learning components is learning materials. As stated by Suparman (2014: 39) that there are six basic components in learning activities, namely: students, graduates who are competent as expected, instructional or learning processes, teachers, curriculum and learning materials.

The module really helps students learn independently because the module contains complete learning content and the module has the power to explain itself and the module is also developed according to student characteristics. This can attract students' attention and increase student interest in learning mathematics. As stated by Suparman, still in the same book, the modules are arranged by structuring the learning content into a special format so that students can learn it independently, without depending on the presence of the teacher continuously.

Problems in mathematics are in the form of problems that are challenging and cannot be solved routinely. Successful problem solving is not possible without proper representation of the problem for the first time (Sajadi, Amiripour \& Rostamy-Malkhalifeh, 2013: 2). According to Marsigit (2012) problem solving can encourage students to think logically, consistently, systematically and develop a documentation / note system, and can develop skills and skills to solve problems. Because solving mathematical problems is very important in learning mathematics, a student must have the ability to solve mathematical problems. In addition to the ability to solve mathematical problems, the focus of researchers is also the ability of mathematical connections. Mathematical connection ability is one of the abilities in obtaining various information needed to solve mathematical problems that students must have to connect various concepts in mathematics and mathematical concepts with other scientific concepts.

\section{LITERATURE REVIEW}

\subsection{Learning System with Modules}

The module can be used by students in learning mathematics. Modules are learning materials that are arranged systematically according to a certain curriculum, packaged in the smallest learning unit and allow students to learn independently within a certain time (Purwanto, Rahadi \& Lasmono, 2007: 9).

Furthermore, Suparman (2014: 317-319) says that the module consists of two kinds of materials, namely learning materials that will be used by students and guideline materials for tutors or teachers. In the learning materials, there are learning contents, learning guidelines for students, and independent learning outcome assessment tools. Modules are also the backbone of learning activities that focus on students' independent learning activities. Suparman also said, still in the same book, that the modules were arranged by structuring the learning content into a special format so that students could learn it independently, without depending on the presence of the teacher continuously. Autograph-assisted mathematics module is a form of mathematics learning material whose learning activity is assisted by an autograph which is used to be studied independently in a certain time unit.

\subsection{Mathematical Problem Solving Ability}

According to Szabo \& Andrews (2017), problem-solving tasks are expected to reveal the mathematical competences needed to solve them, not remembering problems that were previously solved. The problem-solving 
process begins after the problem solver produces enough information about the problem space to gain an understanding of the problem (Dixon \& Brown, 2012: 4). Problem solving is a process where previously obtained data is used in new and unknown situations to solve a problem. As stated by Das, Ranjan; Das, Chandra (2013: 1) thatProblem-solving skills are like vehicles for students to construct their own ideas, enhance logical thinking, transfer skills to unfamiliar situations and to take responsibility for their own learning development.

\subsection{Mathematical Connection Capability}

According to Ozgen (2013: 306) in mathematics education, connection involves the connection of mathematics to the real world, other disciplines, and other concepts of mathematics. According to Umay in Ozgen (2013: 306) the connection between mathematics and the real world not only facilitates understanding but also contributes to making abstract subjects concrete and real.In addition, mathematical connections help students provide a mathematical model that explains the relationship between concepts, data and situations (Hendriana, Slamet, \& Sumarno, 2014: 2). So a mathematical connection is very important in providing an understanding of the material studied in mathematics learning. Real-world connections in mathematics are often cited as a way to increase student motivation (Karakoç and Cengiz Alacac1, 2015: 33). According to Rohendi, Dedi (2012: 3), a mathematical connection is the capacity above information provided with a critical attitude to evaluate something and has metacognitive awareness and problem solving abilities.

\section{RESEARCH METHODS}

This type of research is a Research and Development (Research Development). In this study, researchers developed a mathematics module assisted by autographs. This research was conducted at SMA MAN 1 Deli Serdang, Medan City. The reason for choosing the location of this research is because the school still has not used autographassisted modules in mathematics learning and it is necessary to improve the problem-solving abilities and mathematical connections of students at the school. When this research was conducted in the even semester of the 2020/2021 school year. Subjects in this study were students of SMA MAN 1 Deli Serdang class XI-1 (eleven one) and class XI-2 (eleven two).

\section{RESEARCH RESULT}

The development of this autograph-assisted mathematics module is in accordance with the Dick \& Carey development model procedure which is described as follows.

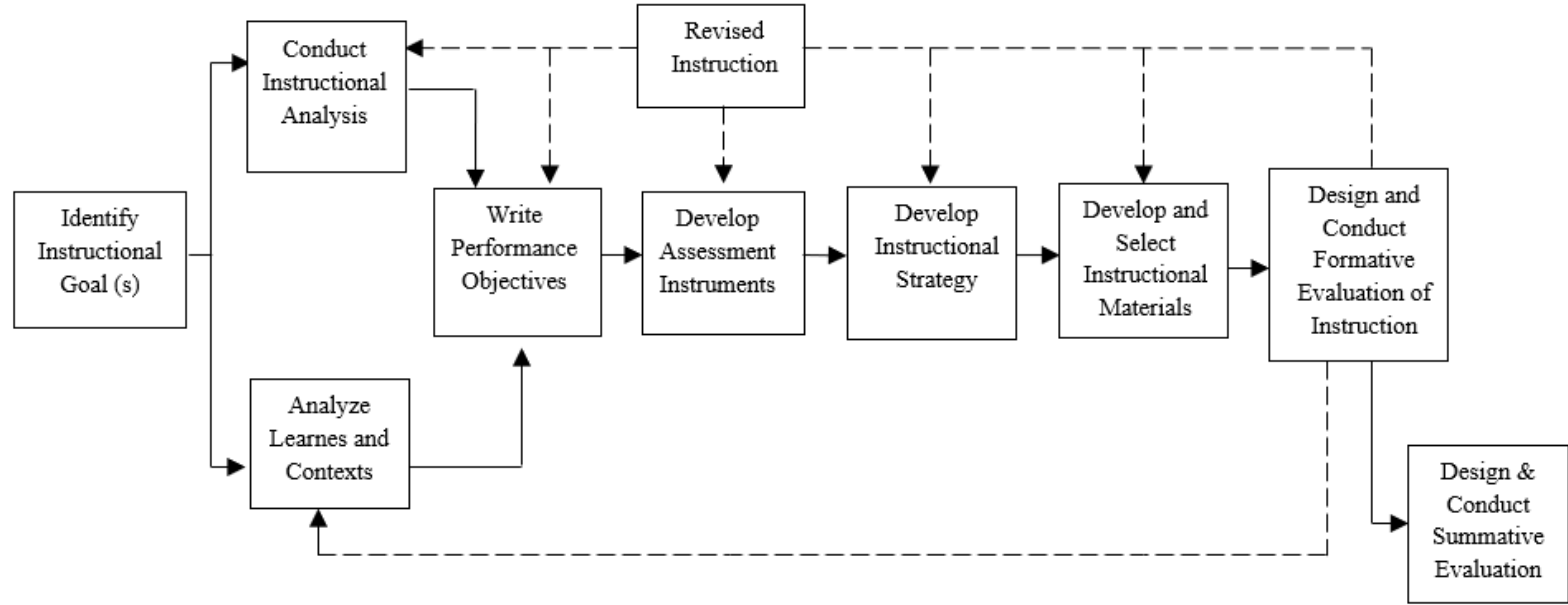

Figure 1 The Dick and Carey Learning Design Model (Dick, Carey \& Carey, 2005: 1-2)

Based on the tests given to students, it is known that the students' problem solving abilities and mathematical connections are low. Based on the test results tested on 30 students. The test given is a test of students' problemsolving abilities and mathematical connections. The students' completeness requirements for the problem-solving ability test and the mathematical connection ability test are a minimum of students who get a B- or 2.67. The results of the mathematical problem-solving ability test obtained are shown in table 1 below: 
Table 1. Results of Student Knowledge Analysis for Ability

Test Mathematical Problem Solving

\begin{tabular}{|c|c|c|c|}
\hline Knowledge Completeness Value & Many Students & Percentage & Information \\
\hline A & 0 & 0 & Completed \\
\hline A- & 0 & 0 & Completed \\
\hline B + & 3 & 10 & Completed \\
\hline B & 6 & 20 & Completed \\
\hline B- & 2 & 5 & Completed \\
\hline C + & 6 & 20 & Not complete \\
\hline C & 7 & 25 & Not complete \\
\hline C- & 4 & 15 & Not complete \\
\hline D + & 2 & 5 & Not complete \\
\hline D & 0 & 0 & Not complete \\
\hline Total & 30 & 100 & \\
\hline
\end{tabular}

From table 1, it is known that as many as two students (5\%) obtained a D + value, as many as four students $(15 \%)$ obtained a $\mathrm{C}$ - score, as many as seven students $(25 \%)$ obtained a $\mathrm{C}$ value, as many as six students $(20 \%)$ obtaining a $\mathrm{C}+$ score, as many as two students $(5 \%)$ obtained a B- score, six students $(20 \%)$ obtained a B grade, and as many as three students $(10 \%)$ obtained a B + grade. So that only eleven students or $35 \%$ who complete (get a minimum grade of B-). Likewise, the results of the analysis of students' knowledge for the mathematical connection ability test were obtained, as shown in table 2 below:

Table 2. Results of Student Knowledge Analysis for Tests

Mathematical Connection Capability

\begin{tabular}{|c|c|c|c|}
\hline Knowledge Completeness Value (alphabet) & Many Students & Percentage (\%) & Information \\
\hline A & 0 & 0 & Completed \\
\hline A- & 0 & 0 & Completed \\
\hline B + & 0 & 0 & Completed \\
\hline B & 2 & 5 & Completed \\
\hline B- & 6 & 20 & Completed \\
\hline C & 8 & 25 & Not complete \\
\hline C & 3 & 10 & Not complete \\
\hline C- & 3 & 10 & Not complete \\
\hline D + & 4 & 15 & Not complete \\
\hline D & 4 & 15 & Not complete \\
\hline Total & 30 & 100 & \\
\hline
\end{tabular}

From table 2, it is known that four students $(15 \%)$ got a $\mathrm{D}$ grade, four students $(15 \%)$ got a $\mathrm{D}+$ score, three students $(10 \%)$ got a $\mathrm{C}$-, three students $(10 \%)$ got a C , eight students $(25 \%)$ got a $\mathrm{C}+$ score, six students $(20 \%)$ got a B- and two students (5\%) got a B grade. So that students who complete (get a minimum grade of B-) are only 8 people or $25 \%$. From these results, it appears that the students' mathematical connection ability is still low.

Based on the indicators of module effectiveness, the results of the research are obtained; First, the completeness of learning on the mathematical problem solving abilities of class XI-2 students, namely $95 \%$ of students who took part in the learning achieved a value of 2.67 or B-. Second, learning completeness on students' mathematical connection ability. From the results of the study, the completeness of learning on the mathematical connection ability of class XI-2 students, namely $90 \%$ of students who took part in learning achieved a value of 2.67 or B-. Third, the achievement of the ideal percentage of student activity in class XI-2 is in accordance with what has been determined.

Fourth, the achievement of the teacher's ability to manage learning in class XI-2 is very good. Fifth, $85 \%$ of the many class XI-2 students studied gave a positive response to the components and learning activities. Because the five indicators of the module's effectiveness have been fulfilled in class XI-2, it can be said that the module being developed has been effective.

\section{CONCLUSION}

Based on the research results that have been obtained, it is concluded that:

1. The autograph-assisted mathematics module developed was effective in improving students' problem-solving and mathematical connection abilities by fulfilling the five effectiveness indicators in the second trial, namely:

a. Complete learning on the mathematical problem solving abilities of students who get a minimum score of 2.67 or B- reaches $95 \%$,

b. The completeness of learning towards the mathematical connection ability of students who get a minimum score of 2.67 or B- reaches $90 \%$, 
c. The achievement of the percentage of ideal time for student activities has been in accordance with what has been determined, namely the six categories of student activity are met with a tolerance of 5\%.

d. The achievement of the teacher's ability to manage learning is very good,

e. $\quad 85 \%$ of the many subjects studied gave a positive response to learning components and activities.

2. The increase in students' mathematical problem-solving abilities in the application of the autograph-assisted mathematics module was 0.19 with the average value of the results of the mathematical problem-solving ability test in the first trial which was obtained was 2.99. Whereas in the second trial, the average value of the mathematical problem solving ability test results was 3.18 .

3. The increase in students' mathematical connection ability in the application of the autograph-assisted mathematics module was 0.43 with the average value of the mathematical connection ability test results obtained in the first trial was 2.73. Whereas in the second trial, the average value of the mathematical connection ability test results was 3.16 .

\section{BIBLIOGRAPHY}

Das, Ranjan \& Das, Gunendra Chandra. 2013. Math Anxiety: The Poor Problem Solving Factor in School Mathematics.International Journal of Scientific and Research Publications, Vol. 3, Issue 4.

Dick, W., Carey, L., \& Carey, JO 2005. The Systematic Design of Instruction, Sixth Edition. Boston.

Dixon, RA, Brown RA 2012. Transfer of Learning: Connecting Concepts During Problem Solving. Journal of Technology Education. Vol. 24 (1): 2-17.

Hendriana, H., Slamet, UR \& Sumarno, U. 2014. Mathematical Connection Ability And Self-Confidence(An Experiment On Junior High School Students Through Contextual Teaching And Learning With Mathematical Manipulative). International Journal of Education. Vol. 8 (1).

Karakoç, G. \& Alacac1, C. 2015.Real World Connections in High School Mathematics Curriculum and Teaching. Turkish Journal of Computer and Mathematics Education. Vol. 6 (1): 31-46.

Marsigit. 2012. Research Studies (International Journal Review) Mathematics Education S2 Mathematics Education. PPS UNY.

Ozgen, Kemal. 2013. Self-Efficacy Beliefs in Mathematical Literacy and Connections Between Mathematics and Real World: The Case Of High School Students. Journal of International Education Research - Fourth Quarter. Vol. 9 (4).

Purwanto, Rahadi, A., Lasmono, S. 2007. Module Development. Jakarta: Ministry of National Education Center for Information and Communication Technology Education.

Rohendi, Dedi.2012. Developing E-Learning Based on Animation Content for Improving Mathematical Connection Abilities in High School Students. IJCSI International Journal of Computer Science Issues. Vol. 9 (1), Issue 4.

Sajadi, M, Amiripour, P., Rostamy-Malkhalifeh, M. 2013. The Examining Mathematical Word Problems Solving Ability under Efficient Representation Aspect. Mathematics Education Trends and Research. 1-11.

Suparman, M. Atwi. 2014. Modern Instructional Design. A Guide for Educational Teachers and Innovators. Jakarta: Erlangga.

Szabo, A. \& Andrews, P. 2017. Examining the interaction of mathematical abilities and mathematical memory: A study of problem solving activity of high-achieving Swedish upper secondary students. The Mathematics Enthusiast. Vol. 14 (1,2 \& 3): 141-160. 